\title{
STOSUNKI IRAŃSKO-TURECKIE NA POCZĄTKU XXI WIEKU: IMPLIKACJE DLA REGIONU BLISKIEGO WSCHODU
}

Turcja i Iran należą bez wątpienia do grupy regionalnych mocarstw na Bliskim Wschodzie. Porównywalnym potencjałem dysponują jeszcze tylko dwa państwa - Arabia Saudyjska oraz Egipt. Jednak to właśnie Turcja i Iran, zwłaszcza w porównaniu $\mathrm{z}$ innymi państwami w regionie, dysponują największym potencjałem demograficznym, politycznym, gospodarczym oraz militarnym. Ponadto, posiadają szerokie wpływy wśród państw muzułmańskich. Turcja zwłaszcza w tych, w których dominują sunnici, natomiast Iran w zdominowanych przez szyitów. Dodatkowo, z różnych powodów, Turcja oraz Iran stanowią przedmiot zainteresowania czołowych światowych graczy takich jak Stany Zjednoczone, Federacja Rosyjska, Chińska Republika Ludowa czy Unia Europejska. Decyduje o tym zwłaszcza ich położenie w regionie Bliskiego Wschodu oraz bezpośrednie sąsiedztwo Kaukazu oraz Azji Środkowej.

Świadomość własnej siły, potencjału i możliwości wpływania na najbliższe otoczenie geopolityczne determinuje cele polityki zagranicznej państwa. W takich okolicznościach nie może nikogo dziwić fakt, że Iran i Turcja posiadały i nadal posiadają wiele rozbieżnych interesów, które choć nigdy nie doprowadziły do wybuchu konfliktu zbrojnego, skutkowały wysokim poziomem wzajemnej nieufności oraz licznymi napięciami w stosunkach dwustronnych. Powyższa uwaga dotyczy przede wszystkim okresu po 1979 roku - roku zwycięstwa sił rewolucyjnych i ustanowienia Islamskiej Republiki Iranu. Podczas gdy Turcja, rządzona przez wojskowych, w pierwszej połowie lat osiemdziesiątych pozostawała kluczowym sojusznikiem Stanów Zjednoczonych na Bliskim Wschodzie, irańskie władze zaczęły prowadzić rywalizacyjną politykę względem USA, która szybko doprowadziła do zerwania stosunków dyplomatycznych ${ }^{1}$.

\footnotetext{
1 Bezpośrednią przyczyną zerwania stosunków dyplomatycznych pomiędzy Iranem a Stanami Zjednoczonymi był incydent związany z okupacją ambasady USA w Teheranie oraz przetrzymywaniem jej pracowników jako zakładników przez uzbrojone grupy irańskich studentów w okresie od listopada 1979 do stycznia 1981 roku. 7 kwietnia 1980 roku Stany Zjednoczone zerwały stosunki dyplomatyczne z Iranem. Pomimo upływu ponad 30 lat nic nie wskazuje na możliwość zmiany tej sytuacji. Więcej na temat incydentu zob. M. Bowden, Guests of the Ayatollah. The Iran Hostage Crisis: the First Battle in America's War with Militant Islam, Grove Press, New York 2006. Więcej na temat stosunków irańsko-amerykańskich zob. W. O. Beeman, The „, Great Satan” vs. the „,Mad Mullahs”: How the United States and Iran Demonize Each Other, Praeger, Westport 2005; A. H. Cook, J. Roshandel, The United States and Iran: Policy Challenges and Opportunities, Palgrave Macmillan, New York 2009; M. A. Mousavi, Y. Norouzi, Iran-US Nuclear Standoff: A Game Theory Approach, „Iranian Review of Foreign Affairs" 2010, vol. 1, no. 1; K. M. Pollack, The Persian Puzzle: the Conflict Between Iran and America, Random House, New York 2005; H. S. Seifzadeh, Islamic Republic's
} 
Stosunki dwustronne uległy wyraźnej poprawie w latach dziewięćdziesiątych, ale było to bardziej wynikiem politycznej kalkulacji aniżeli wspólnoty interesów. Główną przyczyną takiego stanu rzeczy były przede wszystkim głębokie różnice światopoglądowe pomiędzy przedstawicielami władz w obu państwach. Podczas gdy w Iranie decydujący głos mieli duchowni, w Turcji główną siłę polityczną stanowił obóz kemalistowski, podkreślający republikański i sekularny charakter państwa. Sytuacja zmieniła się dopiero w 2002 roku, gdy władzę w Turcji przejęła konserwatywna Partia Sprawiedliwości i Rozwoju (AKP). Z pewnością nie jest ona partią islamska, jak bywa czasem mylnie określana, natomiast deklaruje przywiązanie do zasad demokratycznych, a w kwestiach gospodarczych opowiada się za wolnym rynkiem. Jednakże jednocześnie członkowie AKP podkreślają znaczenie islamu w sferze obyczajowej oraz konieczność promowania podstawowych jego wartości w życiu społecznym. Tym samym rząd naraża się na krytykę ze strony polityków opozycji, którzy wprost oskarżają AKP o próbę zawoalowanej zmiany ustroju i jego dalszą ewolucję w kierunku modelu irańskiego, czyli państwa teokratycznego. Krytyka dotyczy także realizacji polityki zagranicznej. Teoria spisku, rozpowszechniana głównie przez kręgi wojskowych i zlaicyzowane elity, zyskuje niespodziewanie na znaczeniu, jeśli wziąc pod uwagę ocenę rządów AKP w Iranie. Polityka rządu Recepa Tayyipa Erdoğana wzbudza zaufanie władz Islamskiej Republiki Iranu, które dotychczas wielokrotnie krytykowały Turcję za sprzeniewierzenie się zasadom i odejście od podstawowych wartości islamu².

Niniejszy artykuł poświęcony jest analizie stosunków irańsko-tureckich w pierwszej dekadzie XXI wieku, gdy zauważalne stało się polityczne i ekonomiczne zbliżenie pomiędzy Turcją i Iranem. Tym samym najważniejsze pytanie dotyczy przyczyn takiego stanu rzeczy oraz możliwych implikacji dla całego regionu Bliskiego Wschodu.

\section{UWARUNKOWANIA STOSUNKÓW IRAŃSKO-TURECKICH}

Od lat trzydziestych aż do momentu zwycięstwa rewolucji w Iranie w 1979 roku stosunki irańsko-tureckie należy ocenić jako bardzo dobre lub poprawne ${ }^{3}$. Oba państwa utrzymywały ożywione kontakty polityczne i gospodarcze. Począwszy od lat trzydziestych XX wieku reformy polityczne i obyczajowe w Iranie były inspirowane przez sukces kemalizmu w Turcji. Szach Reza Pahlawi nie ukrywał swej fascynacji reformatorską polityką Mustafy Kemala Atatürka. W podobnym duchu starał się modernizować państwo także jego syn - Mohammad Reza Pahlawi, który dążył do uzyskania przez Iran statusu mocarstwa regionalnego.

Two-Tier Foreign Policy Towards the US from Suspicious in the Mid-term to Proactive in the Long-term, „Iranian Review of Foreign Affairs” 2010, vol. 1, no. 2; B. Slavin, Bitter Friends, Bossom Enemies: Iran, the U.S., and the Twisted Path to Confrontation, St. Martin's Press, New York 2007.

2 W przeszłości irańskie władze wielokrotnie krytykowały Turcję za, między innymi, zakaz noszenia chust przez kobiety na terenie kampusów uniwersyteckich, brak nakazów określających prawidłowy ubiór kobiety w miejscach publicznych czy brak zakazu sprzedaży i spożywania alkoholu.

3 Więcej o korzeniach rewolucji islamskiej w Iranie zob. A. Khaliqi, Legitimacy of Power from Imam Khomeini's Point of View, The Institute for Compilation and Publication of Imam Khomeini's Works, Tehran 2004; The Islamic Revolution in Iran, Ansariyan Publications, Qum 1990. 
Ponadto, oba państwa łączyła bliska współpraca ze Stanami Zjednoczonymi. Zarówno Turcja, jak i Iran, państwa graniczące ze Związkiem Radzieckim, odgrywały bardzo ważną rolę w zimnowojennej polityce zagranicznej USA. W Iranie „w latach pięćdziesiątych i sześćdziesiątych rola Wielkiej Brytanii systematycznie malała, ustępując miejsca wpływom Stanów Zjednoczonych. Na początku lat pięćdziesiątych władzę w Iranie przejął charyzmatyczny premier Mosaddek, który próbował uniezależnić Iran od wpływów zewnętrznych i znacjonalizować przemysł wydobywczy. Jego konflikt z szachem Mohammadem Rezą Pahalawim został wykorzystany przez Stany Zjednoczone, które obiecały młodemu monarsze powrót na tron w Iranie w zamian za pełne podporządkowanie polityce USA. Zamach stanu, inspirowany i zorganizowany przez CIA, zakończył się powodzeniem, ale jednocześnie przysporzył wielu wrogów zarówno szachowi, jak i USA. Według niektórych historyków, to właśnie zamach stanu z 1953 roku i wywołane nim poczucie krzywdy stały się jednymi z przyczyn gwałtownego wybuchu niezadowolenia społecznego w Iranie w $1978 \mathrm{roku}^{4}$. W okresie rządów ostatniego szacha stosunki turecko-irańskie były poprawne, tym bardziej, że leżało to w interesie Stanów Zjednoczonych. Współpraca Iranu z Turcją oraz kontrola nad ich władzami stanowiły gwarancję utrzymania amerykańskich wpływów w regionie oraz skuteczną ochronę przed ewentualną ekspansją ze strony Związku Radzieckiego ${ }^{5}$.

Po 1953 roku mosaddekowska koncepcja negatywnej równowagi w polityce zagranicznej została zastąpiona koncepcją silnych związków z USA dla przeciwstawienia się groźbie komunistycznej ekspansji. „Na płaszczyźnie regionalnej wyrazem tego było przystapienie Iranu (1955) do polityczno-wojskowego paktu bagdadzkiego, powstałego z inspiracji Stanów Zjednoczonych, chociaż formalnie nie weszły one w skład paktu. Pozostałymi państwami członkowskimi były Turcja, Pakistan, Wielka Brytania oraz Irak" ${ }^{\prime \prime}$. Po wystapieniu Iraku, Pakt Bagdadzki został przemianowany na Organizację Paktu Centralnego (CENTO), który rok później, w 1959 roku, został wzmocniony dwustronnymi porozumieniami o współpracy wojskowej pomiędzy Stanami Zjednoczonymi a Iranem, Turcją i Pakistanem ${ }^{7}$. Tym samym przez ponad dwadzieścia lat zarówno Iran, jak i Turcja, były amerykańskimi sojusznikami na Bliskim Wschodzie, przesądzając o zimnowojennym układzie sił $\mathrm{w}$ tym regionie świata.

Sytuacja uległa zmianie dopiero w 1979 roku po odsunięciu od władzy szacha Rezy Mohammada Pahlawiego. Zwycięstwo sił rewolucyjnych i będące jego konsekwencją zmiany ustrojowe w Iranie zdeterminowały także stosunki tego państwa z Turcją. Bez wątpienia to właśnie Turcja najbardziej skorzystała na politycznym przewrocie w Iranie, stając się głównym obok Izraela sojusznikiem Stanów Zjednoczonych w regionie Bliskiego Wschodu. Jednocześnie dzięki zręcznej polityce ówczesnego premiera Turguta Özala, zachowała 'pozytywną neutralność' w trakcie wojny iracko-irańskiej.

4 Więcej na temat zamachu stanu z 1953 zob. S. Kinzer, All the Shah's Men. An Amercian Coup and the Roots of Middle East Terror, John Wiley \& Sons, Hoboken 2008.

5 W tamtym okresie władze w obu państwach wyjątkowo okrutnie obchodziły się z komunistami oraz członkami różnych grup lewicowych.

6 A. Krasnowolska, Iran wspótczesny, w: Historia Iranu, red. A. Krasnowolska, Ossolineum, Wrocław 2010, s. 860.

7 I. Paczkowska, Cesarstwo Iranu, Krajowa Agencja Wydawnicza, Warszawa 1977, s. 82. 
Zyskała także większą przychylność ze strony NATO jako przeciwwaga dla prób eksportu idei irańskiej rewolucji ${ }^{8}$.

Niemniej w Turcji lat osiemdziesiątych i dziewięćdziesiątych, pomimo obiekcji ze strony Stanów Zjednoczonych czy Izraela, dominowało przekonanie o tym, iż Iran jest dużym, sąsiednim państwem, z którym warto raczej poszukiwać konsensusu aniżeli ryzykować konfrontację. Nie oznacza to jednak, że tureckie władze były pasywne i nie podejmowały żadnych działań w momencie, gdy postępowanie Iranu zagrażało interesom Turcji. Na przykład, „w 1989 roku Turcja wezwała swego ambasadora z Teheranu na konsultacje po fali irańskiej krytyki wywołanej decyzją sądu najwyższego, dotyczącej zakazu noszenia chust przez kobiety na terenie kampusów uniwersyteckich. Oficjalnej krytyce towarzyszyły liczne antytureckie ataki w irańskich mediach"”. Nie zmienia to jednak faktu, iż po różnych incydentach każdorazowo następowała szybka poprawa we wzajemnych stosunkach i powrót do realizacji długofalowej polityki względem sąsiada.

Według Rafała Ożarowskiego, „zgodnie z chomeinistyczną percepcją islam jest wszystkim - polityką, gospodarką, etyką filozofią. Islam został wyniesiony do najwyższej idei, którą Chomeini, w przeciwieństwie do innych ideologii, uznał za jedyną

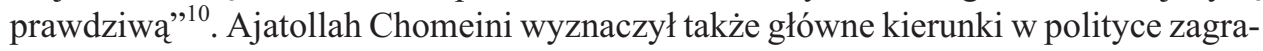
nicznej Iranu po 1979 roku. Podstawę stanowi zgodność wszelkich podejmowanych działań oraz zawieranych umów z prawem koranicznym. W jednym z pism A. Chomeini podkreślił: ,Jeśli sens umowy o charakterze politycznym lub ekonomicznym, zawartej z państwem muzułmańskim lub nie, byłby sprzeczny z zasadami islamu lub interesami muzułmanów, pozostałe państwa muzułmańskie powinny ostro zareagować przy użyciu wszelkich dostępnych środków" ". Przywódca irańskiej rewolucji podkreślił również konieczność upowszechniania doświadczeń i osiagnięć Iranu na całym świecie $^{12}$. Takie założenie wywołało zaniepokojenie nie tylko w rządzonych autorytarnie państwach arabskich, ale także w Turcji.

Ze względu na istotne różnice ideologiczne, lata osiemdziesiąte i dziewięćdziesiąte zaowocowały pogłębianiem się politycznych różnic pomiędzy Turcją a Iranem. Szeroki katalog rozbieżności musiał zdeterminować ich stosunki dwustronne, a także negatywnie wpłynął na sytuację w regionie Bliskiego Wschodu. Graham E. Fuller do najważniejszych, współczesnych uwarunkowań stosunków turecko-irańskich zaliczył:

- kwestię kurdyjską, która wpływa nie tylko na stosunki dwustronne, ale także na stosunki w układzie Turcja-Iran-Irak;

- spory ideologiczne, zwłaszcza jeśli wziąć pod uwagę wpływ religii na politykę państwa;

8 P. Robins, Suits and Uniforms. Turkish Foreign Policy Since the Cold War, Hurst \& Company, London 2003, s. 57.

9 Ibidem, s. 254.

10 R. Ożarowski, Ideologia na Bliskim Wschodzie, Wydawnictwo Uniwersytetu Gdańskiego, Gdańsk 2006, s. 45-46.

${ }^{11}$ Imam Khomeini, Fundamentals of the Islamic Revolution: Selections from the Thoughts and Opinions, The Institute for Compilation and Publication of Imam Khomeini's Works, Tehran 2000, s. 480 .

12 Ibidem, s. $480-481$. 
- sprzeciw Turcji wobec zbyt radykalnych deklaracji lub działań ze strony irańskich władz;

- geopolityczną rywalizację o wpływy w Iraku, Syrii, regionie Zatoki Perskiej, na Kaukazie oraz w Azji Centralnej;

- irański program atomowy;

- politykę energetyczną Turcji, zwłaszcza w kontekście rozbudowy infrastruktury pod kątem przyszłego przesyłania irańskiego gazu ziemnego;

- panturecką wizję polityki zagranicznej Turcji, zarzuconą przez rząd AKP, ale nadal możliwą do realizacji;

- zagrożenie ewentualną, niekontrolowaną zmianą systemową w Iranie wywołaną, na przykład, przez interwencję ze strony Stanów Zjednoczonych ${ }^{13}$.

Pierwszym pozytywnym sygnałem możliwej poprawy w relacjach irańsko-tureckich był wybór na prezydenta Iranu Mohammada Chatamiego w maju 1997 roku. Nowy prezydent, znany z ugodowej postawy, pozwalał liczyć nie tylko na stopniową liberalizację $\mathrm{w}$ ramach polityki wewnętrznej, ale także na istotną zmianę $\mathrm{w}$ ramach polityki zagranicznej Iranu. Koncyliacyjna postawa M. Chatamiego w wielu kluczowych kwestiach, na przykład, złagodzenie retoryki pod adresem Stanów Zjednoczonych, stwarzały szansę na nowe otwarcie w ramach stosunków dwustronnych Iranu i Turcji ${ }^{14}$.

Niemniej, głównym problemem we wzajemnych stosunkach pozostawał deficyt zaufania, zwłaszcza w kwestiach związanych $\mathrm{z}$ bezpieczeństwem. Ismail Cem, pełniący funkcję ministra spraw zagranicznych w latach 1997-2002, zwracał uwagę przede wszystkim na aktywność kurdyjskich grup terrorystycznych, które miały znajdować schronienie w Iranie i stamtąd atakować cele na tureckim terytorium ${ }^{15}$. Jak słusznie zauważył Mariusz Hoffman, na początku XXI wieku część tureckich polityków dążyła „nie do polepszania stosunków z Islamską Republiką Iranu, lecz do jej okrążania i izolowania" ${ }^{\prime 16}$. Jednym z elementów tej polityki miało być ściślejsze powiązanie Azerbejdżanu z Turcją, jednakże pomimo dynamicznego rozwoju stosunków turecko-azerskich Azerbejdżan utrzymał bardzo dobre relacje z Teheranem. W ostatnich latach Iran nawet wzmocnił swoją pozycję w Azerbejdżanie po tym, gdy Turcja podjęła próbę normalizacji stosunków z jego największym przeciwnikiem - Armenią ${ }^{17}$. Ponadto, należy mieć na uwadze, że chociaż Azerowie są narodem pochodzenia tureckiego, ze względu na dominację szyizmu bliżej im do Iranu aniżeli do zdominowanej przez

13 G. E. Fuller, The New Turkish Republic. Turkey As a Pivotal State in the Muslim World, United States Institute of Peace Press, Washington 2010, s. 108.

14 Prezydent Chatami odważył się, między innymi, wyrazić ubolewanie z powodu okupacji amerykańskiej ambasady w latch 1979-1981 oraz potępił przypadki palenia amerykańskich flag podczas demonstracji w Iranie. Zob. T. Parsi, Treacherous Alliance: The Secret Dealings of Israel, Iran and the U.S., Yale University Press, New Haven-London 2008, s. 205.

${ }_{15}$ I. Cem, Turkey in the New Century, Rustem Publishing, Nicosia 2001, s. 87.

16 M. Hoffman, Regionalne oddziaływania Islamskiej Republiki Iranu (1979-1999), Wydawnictwo Akademii Świętokrzyskiej, Kielce 2002, s. 106.

${ }^{17} \mathrm{O}$ kwestiach spornych oraz procesie normalizacji w stosunkach turecko-ormiańskich zob. S. Idiz, The Turkish-Armenian Debacle, ,Insight Turkey” 2010, vol. 12, no. 2; A. Iskandaryan, Armenian-Turkish Rapprochement: Timing Matters, „Insight Turkey” 2009, vol. 11, no. 3; S. Minasyan, Prospects for Normalization between Armenia and Turkey, „Insight Turkey” 2010, vol. 12, no. 2. 
sunnitów Turcji ${ }^{18}$. W przypadku państw muzułmańskich wpływ czynnika religijnego na ich wzajemne stosunki jest istotniejszy aniżeli czynnik narodowościowy.

Jak słusznie zauważył wiceminister spraw zagranicznych Islamskiej Republiki Iranu Manouchehr Mohammadi, „trzy duże wojny w regionie Zatoki Perskiej, wojna w Afganistanie, niestabilność w Azji Zachodniej, sytuacja w Iraku oraz na Bliskim Wschodzie dowodza, że Iran jest położony w wyjątkowo trudnym otoczeniu geopolitycznym, zwłaszcza jeśli wziąć pod uwagę kwestię bezpieczeństwa"19. Chociaż Iran był zaangażowany bezpośrednio jedynie w pierwszą wojnę w Zatoce Perskiej, czyli w wojnę iracko-irańska, pozostałe wydarzenia w regionie nie pozostawały i nie pozostają bez silnego wpływu na sytuację w tym państwie. Wojna w Iraku w 2003 roku sprawiła, że w bezpośrednim sąsiedztwie Iranu znalazły się liczne siły zbrojne Stanów Zjednoczonych oraz Wielkiej Brytanii. Z kolei wojna w Afganistanie skutkuje niepokojem we wschodniej części Iranu, gdzie mają miejsce liczne potyczki pomiędzy irańskim wojskiem a grupami przemycającymi afgańskie narkotyki. Z perspektywy irańskiej sytuację geopolityczną komplikuje dodatkowo istnienie państwa Izrael, którego politykę władze Iranu oceniają jako agresywną i zbrodniczą ${ }^{20}$. Zastrzeżenia budzą przede wszystkim ostra krytyka irańskiego programu atomowego ze strony Izraela, formułowanie gróźb pod adresem Iranu, wojna w południowym Libanie w 2006 roku oraz złe traktowanie Palestyńczyków (blokada Strefy Gazy).

\section{PRZEJĘCIE WLADZY W TURCJI PRZEZ PARTIĘ SPRAWIEDLIWOŚCI I ROZWOJU: WPLYW NA POLITYKĘ ZAGRANICZNĄ}

Partia Sprawiedliwości i Rozwoju (AKP) wygrała wybory parlamentarne w Turcji i utworzyła rząd w listopadzie 2002 roku. Zwycięstwo partii kierowanej przez Recepa Tayyipa Erdoğana wywołało niepokój na Zachodzie, ponieważ AKP była przestawiana przez rządzące do tamtej pory elity jako partia wsteczna, konserwatywna i antyzachodnia. Jak się miało wkrótce okazać, obawy były bezpodstawne. Co więcej, to właśnie za rządów AKP nastapił prawdziwy przełom w polityce zagranicznej Turcji, a zwłaszcza zintensyfikowanie działań celem otwarcia negocjacji akcesyjnych z Unią Europej$\mathrm{ską}^{21}$. Jednocześnie wydarzenia w Ankarze nie mogły pozostać niezauważone w Iranie, którego władze pozytywnie oceniały zmiany polityczne u zachodniego sąsiada. Zwłaszcza że w przedwyborczych deklaracjach polityków AKP zawarta była zapowiedź wyraźnej poprawy stosunków z wszystkimi sąsiadującymi z Turcją państwami, włączając $\mathrm{w}$ to Iran.

Jeden z filarów polityki zagranicznej Turcji za rządów AKP stanowi polityka eliminacji problemów w stosunkach z państwami sąsiednimi (ang. zero-problem-with-neigh-

\footnotetext{
${ }^{18}$ Więcej na temat historii Azerbejdżanu zob. T. Świętochowski, Azerbejdżan, Trio, Warszawa 2005.

19 M. Mohammadi, Principles of Iran's Foreign Policy, „The Iranian Journal of International Affairs" 2007, vol. XIX, no. 1, s. 6-7.

${ }^{20}$ Ibidem.

21 Więcej na temat obecnych przemian politycznych w Turcji i Iranie zob. G. M. Tezcür, Muslim Reformers in Iran and Turkey: the Paradox of Moderation, University of Texas Press, Austin 2010.
} 
bors policy), której autorem jest obecny minister spraw zagranicznych Ahmet Davutoğlu. Jego koncepcja zakładała przedefiniowanie pozycji Turcji z państwa pomostowego na państwo osiowe, którego polityka łączyłaby w sobie wschodnią, muzułmańską tożsamość z zachodnimi wartościami. Polityka eliminacji problemów z państwami sąsiednimi zakładała również aktywne starania na rzecz możliwie najszybszego przystapienia do Unii Europejskiej oraz wprowadzenie nowych, ale konstruktywnych zasad w ramach współpracy ze Stanami Zjednoczonymi. Ostatnie z tych założeń miało zagwarantować zachowanie równowagi między dominującymi w regionie antyamerykańskimi nastrojami a koniecznością dalszego korzystania z amerykańskiej pomocy ${ }^{22}$.

Ahmet Davutoğlu przedstawił swoją wizję odbudowy pozycji Turcji w regionie jeszcze przed przejęciem władzy przez AKP. W 2001 roku ukazała się jego książka Stratejik Derinlik. Türkiye'nin Uluslararası konumu (pol. „Strategiczna głębia. Międzynarodowe położenie Turcji”), wyznaczająca nowe podejście w strategicznych kwestiach dotyczących bezpieczeństwa i rozwoju Turcji ${ }^{23}$. Tym samym, gdy AKP przejęła władzę po wyborach parlamentarnych w listopadzie 2002 roku, idea eliminacji kwestii spornych w stosunkach z sąsiadami zdeterminowała politykę zagraniczną Turcji. Jej stopniowa realizacja stanowiła szansę na dalszą poprawę stosunków z Grecją, przyszłe nawiązanie stosunków dyplomatycznych z Armenią, uregulowanie kwestii cypryjskiej, a także poprawę w ramach stosunków dwustronnych z Syrią oraz Iranem. Przełomowym okazał się rok 2009, który wyznaczył nowe otwarcie w stosunkach Turcji z Armenią, Irakiem i Syrią. W przypadku Syrii zaistniała szansa na strategiczne partnerstwo pomiędzy oboma państwami, które w przyszłości może wzmocnić bezpieczeństwo oraz stworzyć podstawę dla integracji ekonomicznej w regionie ${ }^{24}$. Nie bez znaczenia są $\mathrm{w}$ tym przypadku silne związki między Syrią a Iranem.

Zdaniem Williama Hale'a, trudno nie zgodzić się ze słusznością bieżącej polityki zagranicznej Turcji, zwłaszcza w kontekście eliminacji spornych kwestii w stosunkach z sąsiadami. „Z pewnością lepiej było podjąć próbę rozwiązania niektórych problemów aniżeli kontynuować ksenofobiczną politykę opartą na przekonaniu, że Turcję otaczają wrogowie" 25 . Z pewnością zmiana zainicjowana przez rząd AKP umożliwiła wzmocnienie regionalnej pozycji Turcji. Ponadto, pozwoliła Turcji występować w charakterze pośrednika pomiędzy Syrią a Izraelem czy w sprawie irańskiego programu atomowego.

Politykę zagraniczną Turcji za rządów AKP należy także analizować w kontekście europejskim, zwłaszcza biorąc pod uwagę trwające negocjacje akcesyjne z Unią Europejska. W opinii Volkera Perthesa, ,pomimo paru zastrzeżeń, decydenci z Unii Europejskiej doceniają obecne zaangażowanie Turcji na Bliskim Wschodzie i przeważnie uważają je za pozytywne. W przeciwieństwie do Stanów Zjednoczonych, które po incydencie ze statkiem płynącym do Strefy Gazy stały się bardziej krytyczne i coraz bar-

22 M. H. Yavuz, Secularism and Muslim Democracy in Turkey, Cambridge University Press, Cambridge 2009, s. 202-203.

23 A. Davutoğlu, Stratejik Derinlik. Türkiye'nin Uluslararası konumu, Kure Yayinlari 2001.

24 U. Ulutaş, Turkish Foreign Policy in 2009: A Year of Pro-activity, „Insight Turkey” 2010, vol. 12 , no. 1 , s. 4 .

${ }^{25}$ W. Hale, Turkey and the Middle East in the 'New Era', „Insight Turkey” 2009, vol. 11, no. 3, s. 156. 
dziej sceptycznie oceniają turecką politykę w regionie"26. Niemniej, nie zmienia to faktu, iż w Turcji stopniowo narasta zniecierpliwienie spowodowane przeciagającymi się negocjacjami akcesyjnymi oraz kolejnymi żądaniami ze strony Komisji Europejskiej. Turecki premier Recep Tayyip Erdoğan w jednym ze swych artykułów wyraźnie zaznaczył: „Niektórzy twierdzą, że Turcja nie ma alternatywy poza Europą. To może być prawda, jeśli wziąć pod uwagę poziom ekonomicznego zintegrowania Turcji z rynkiem UE, a także fakt, iż liberalna i demokratyczna Europa zawsze stanowiła punkt wyjścia dla reform w Turcji. Jednocześnie należy jednak podkreślić, że Europa też nie ma alternatywy poza Turcją. Zwłaszcza w warunkach globalnego ładu, w którym zmienia się równowaga sił, Europa potrzebuje Turcji, by stać się silniejszą, bogatszą i bezpieczniejszą"27.

Jednocześnie obok głosów podkreślających brak poważnej alternatywy dla proeuropejskich aspiracji Turcji, pojawiają się także opinie zakładające dalsze umacnianie regionalnej pozycji tego państwa, włącznie z przewodniczeniem potencjalnym, przyszłym procesom integracyjnym na Bliskim Wschodzie.

\section{POLITYKA ZAGRANICZNA IRANU ZA PREZYDENTURY MAHMUDA AHMADINEŻADA}

Podstawowe zasady determinujące cele irańskiej polityki zagranicznej zostały sformułowane już w pierwszym okresie istnienia Islamskiej Republiki Iranu. Ajatollah Chomeini zaliczył do nich:

- współpracę opartą na wiedzy i dialogu, a nie globalizmie i narzucaniu własnych zasad pozostałym aktorom;

- przeciwstawienie się okrucieństwu i przemocy;

- pacyfizm;

- niezależność;

- sprawiedliwość;

- jedność wśród muzułmanów ${ }^{28}$.

Od 1979 roku w irańskim systemie konstytucyjnym czołową rolę w kreowaniu oraz realizacji polityki zagranicznej odgrywa najwyższy przywódca ${ }^{29}$. Drugą osobą w państwie jest prezydent. Przez dziesięć lat funkcję najwyższego przywódcy pełnił lider rewolucji islamskiej Chomeini. Obecny rahbar, ajatollah Ali Chamenei, znany jest ze

26 V. Perthes, Turkey's Role in the Middle East: An Outsider's Perspective, „Insight Turkey” 2010, vol. 12, nr 4, s. 6. Więcej na temat incydentu z udziałem tureckiej floty płynącej do Strefy Gazy zob. I. Lee, Attack on the Gaza Flotilla: An Eyewitness Account, ,Insight Turkey” 2010, vol. 12, no. 3; T. Özhan, Turkey, Israel and the US in the Wake of the Gaza Flotilla Crisis, „Insight Turkey”2010, vol. 12 , no. 3 .

27 R. T. Erdoğan, The Robust Man of Europe: Turkey has the Vigor that the EU badly needs, „Newsweek” z 24 stycznia 2011.

28 A. Eftekhari, The Fixed Principles of the Foreign Policy of the Islamic Republic of Iran With an Emphasis on the Viewpoint of Imam Khomeini, „The Iranian Journal of International Affairs” 2007, vol. XIX, no. 2, s. 34-38.

29 Najwyższego przywódcę duchowego określa się w języku perskim słowem rahbar. 
swych konserwatywnych poglądów. Z tego powodu źle układała się jego współpraca z poprzednim prezydentem Chatamim. Zmiana nastąpiła dopiero po wyborze konserwatysty Mahmuda Ahmadineżada na prezydenta w 2005 roku. Jego wybór był zaskoczeniem dla wielu obserwatorów, także w Iranie, i wpłynął na zasadniczą zmianę w ramach irańskiej polityki zagranicznej ${ }^{30}$. O ile prezydent Chatami starał się poprawić wizerunek Iranu i otworzyć państwo na współpracę ze światem zewnętrznym, a zwłaszcza z państwami Zachodu, Ahmadineżad wygrał wybory, posługując się hasłami antyzachodnimi i antyreformatorskimi ${ }^{31}$.

W porównaniu z okresem prezydentury Mohammada Chatamiego, Mahmud Ahmadineżad zaczął prowadzić wyraźnie konfrontacyjną politykę w stosunku do Zachodu i Izraela ${ }^{32}$. Jego ostre wypowiedzi, zwłaszcza te dotyczące wymazania Izraela z mapy świata oraz podważenie prawdy o Holocauście, sprawiły, że w Stanach Zjednoczonych i wielu państwach zachodnich zaczęto postrzegać Iran w kategoriach głównego zagrożenia dla pokoju i bezpieczeństwa na Bliskim Wschodzie ${ }^{33}$. Między innymi z tego powodu Zachód duże nadzieje wiązał z wyborami prezydenckimi w 2009 roku. Ponowny wybór prezydenta Ahmadineżada oraz tłumienie powyborczych niepokojów społecznych w Iranie, określanych powszechnie mianem zielonej rewolucji, spotkały się z niezadowoleniem ze strony przywódców państw Zachodu i przyczyniły do dalszej eskalacji napięcia w stosunkach z Iranem ${ }^{34}$. Przy okazji, należy jeszcze raz podkreślić, że wielu zachodnich polityków przecenia znaczenie prezydenta w systemie konstytucyjnym Iranu, którego podstawę stanowi zasada welajat-e fakih - rządy uczonego prawnika, czyli najwyższego przywódcy. W praktyce rahbar decyduje o tym, kto może wystartować w wyborach, a kto nie i przysługuje mu ostateczny głos w wielu spornych kwestiach, w tym także dotyczących polityki zagranicznej. Jest to zgodne z wytycznymi sformułowanymi przez imama Chomeiniego. Tym samym prezydent może realizować politykę zagraniczną Iranu jedynie w ramach określonych przez najwyższego przywódcę Ali Chamenei.

Po 2005 roku społeczność międzynarodowa zaczęła kojarzyć politykę zagraniczną Iranu głównie z irańskim programem atomowym, a zwłaszcza domniemanym, tajnym programem wojskowym. Chociaż program został zainicjowany jeszcze za rządów ostatniego szacha, nowa administracja Iranu zintensyfikowała prace nad nim, przyspieszyła realizację głównych inwestycji i przeznaczyła większe środki na badania naukowe ${ }^{35}$.

${ }^{30}$ W drugiej turze Ahmadineżad pokonał faworyzowanego Haszemiego Rafsandżani, zwycięzcę pierwszej tury.

31 Więcej zob. A. Ehteshami, Iran's Regional Policies since the End of the Cold War, w: Contemporary Iran. Economy, Society, Politics, ed. A. Gheissari, Oxford University Press, New York 2009, s. $330-331$.

32 Ciekawa pozycja dotycząca pierwszej kadencji prezydentury Mahmuda Ahmadineżada: H. Majd, Ajatollah śmie watpić, Karakter, Kraków 2010.

33 R. K. Ramazani, Reflections on Iran's Foreign Policy: Spiritual Pragmatism, „Iranian Review of Foreign Affairs" 2010, vol. 1, no. 1, s. 64.

34 Więcej o sytuacji przed i tuż po wyborach prezydenckich w Iranie w 2009 roku zob. M. Kęskrawiec, Czwarty pożar Teheranu, Wydawnictwo W.A.B., Warszawa 2010.

${ }^{35}$ Ciekawej i wyczerpującej wiedzy na temat irańskiego programu atomowego dostarcza publikacja Międzynarodowego Instytutu Studiów Strategicznych. Zob. Iran's Strategic Weapons Programmes: a Net Assessment, Routledge and the International Institute for Strategic Studies, New York 2006. 
Pomimo nałożonych sankcji i wielu ograniczeń, Iran mógł liczyć na współpracę ze strony Federacji Rosyjskiej oraz Chińskiej Republiki Ludowej, co spotykało się z ostrą krytyką zwłaszcza ze strony Stanów Zjednoczonych ${ }^{36}$.

Niemniej, irańskie władze konsekwentnie podkreślają, że prowadzone prace mają wyłącznie charakter pokojowy i nie służą produkcji broni atomowej. Nawet wypowiedzi prezydenta Ahmadineżada dotyczące usunięcia Izraela $\mathrm{z}$ mapy świata nie miały oznaczać woli eksterminacji Izraelczyków, a jedynie chęć likwidacji struktur państwa żydowskiego. Iran potrzebuje energii generowanej w elektrowniach atomowych, by zaspokoić rosnący popyt na rynku wewnętrznym. Niemniej, podejrzenia Stanów Zjednoczonych i ich sojuszników budzą równolegle prowadzone prace w ramach irańskiego programu rakietowego ${ }^{37}$. Iran dysponujący technologią nuklearną oraz środkami przenoszenia miałby stanowić zagrożenie nie tylko w skali regionalnej, ale także globalnej.

Ponadto, Stany Zjednoczone od wielu lat otwarcie oskarżają irańskie władze o wspieranie rozmaitych ugrupowań terrorystycznych na Bliskim Wschodzie, na czele z libańskim Hezbollahem czy Hamasem w Strefie Gazy, ale oskarżenia te przybrały na sile po objęciu prezydentury przez Mahmuda Ahmadineżada ${ }^{38}$. USA zaczęły także zarzucać Teheranowi wspieranie irackich rebeliantów, atakujących cywilów oraz żołnierzy sił koalicyjnych. Z kolei władze Iranu konsekwentnie odrzucały wszelkie oskarżenia i podkreślały, że stabilizacja sytuacji w sąsiednim Iraku pozostaje jednym z priorytetowych celów polityki zagranicznej. Wobec tego w państwach Zachodu pojawiały się nawet głosy, że należy interweniować i odsunacé mułłów od władzy, by ustabilizować sytuację w Iraku, jednakże jakakolwiek racjonalna analiza sytuacji wskazywała, że ewentualny atak na Iran tylko pogorszyłby i tak skomplikowane położenie sił koalicyjnych. Jak słusznie zauważył Dariush Zahedi, „Stanom Zjednoczonym trudno jest promować stabilizację w Iraku i Afganistanie czy wspierać proces pokojowy na Bliskim Wschodzie bez przynajmniej przyzwolenia ze strony Iranu. Na taką zgodę trudno jednak liczyć, jeśli nie zostaną podjęte żadne działania celem rozwiązania długotrwałych sporów między tymi państwami" ${ }^{39}$.

W styczniu i lutym 2011 roku Iran udzielił także wyraźnego poparcia siłom opozycyjnym w Egipcie. Odsunięcie od władzy prezydenta Hosni Mubaraka ocenione zo-

36 P. Jafari, Der Andere Iran, Verlag C.H. Beck, München 2010, s. 166-172.

${ }^{37} \mathrm{Na}$ początku lutego 2011 roku irańska Gwardia Rewolucyjna przeprowadziła pokazowe testy najnowszych rakiet balistycznych typu ziemia-woda o nazwie „Zatoka Perska”. Nowe rakiety są przeznaczone do niszczenia okrętów, a ich zasięg wynosi około $300 \mathrm{~km}$. Wspomnianą demonstrację siły należy uznać za czytelny sygnał pod adresem Stanów Zjednoczonych, których jednostki marynarki wojennej są stale obecne w Zatoce Perskiej. Obecnie USA nie dysponują żadną inną możliwością uderzenia na Iran aniżeli właśnie z wykorzystaniem marynarki wojennej, głównie lotniskowców. W razie jakiejkolwiek próby amerykańskiego ataku, Iran miałby użyć nowych rakiet do obrony swego terytorium. Zob. Iran chwali się nowymi rakietami, http://www.tvn24.pl/12691,1691993,0,1, iran-chwali-sie-nowymi-rakietami,wiadomosc.html (13.02.2011).

38 Więcej o powiązaniach Iranu z Hamasem i libańskim Hezbollahem zob. M. Levitt, Hamas. Polityka, dobroczynność i terroryzm w stużbie dżihadu, Wydawnictwo Uniwersytetu Jagiellońskiego, Kraków 2008; R. Ożarowski, Hezbollah w stosunkach międzynarodowych na Bliskim Wschodzie, Wydawnictwo Uniwersytetu Gdańskiego, Gdańsk 2011.

39 D. Zahedi, Prospects for Democratization in Iran: Policy Implications, „Insight Turkey” 2010, vol. 12 , no. 2 , s. 238. 
stało w Teheranie jako szansa na zmniejszenie wpływów Stanów Zjednoczonych w regionie. Szczególny, symboliczny wymiar miała demonstracja z udziałem członków irańskiego parlamentu 13 lutego 2011 roku. Parlamentarzyści opuścili budynek madżlisu, wznosząc okrzyki „Bóg jest wielki”, „Jedność wśród muzułmanów” oraz „Precz z USA"40. Kwestia czy Iran będzie się starał wypełnić polityczną próżnię w Egipcie czy Libii pozostaje otwarta.

\section{STOSUNKI IRAŃSKO-TURECKIE: PUNKTY ZBIEŻNE W POLITYCE ZAGRANICZNEJ OBU PAŃSTW}

Irański program atomowy jest bacznie obserwowany przez społeczność międzynarodową, w tym przez władze sąsiedniej Turcji. Chociaż turecki rząd nie popiera nakładania kolejnych sankcji na Iran i opowiada się za rozwiązaniem dyplomatycznym, irański program wywołuje niepokój w Ankarze. Jak słusznie zauważa Kadir Üstün, gdyby Iran wszedł w posiadanie broni jądrowej, stanowiłoby to bezpośrednie zagrożenie dla Turcji. Turcja pozostaje rzeczniczką strefy bezatomowej na Bliskim Wschodzie, a Iran nie może w tej sprawie liczyć na wyjątkowe traktowanie. Realizacja irańskiego scenariusza zniweczyłaby dyplomatyczne wysiłki Turcji, zwłaszcza w kontekście budowy nowego ładu w regionie ${ }^{41}$. Warto podkreślić fakt, iż Turcja konsekwentnie wspiera proces dialogu między grupą 5+1 a Iranem $^{42}$. Najlepszym tego przykładem jest fakt zorganizowania jednej z rund rokowań w Stambule ${ }^{43}$. Chociaż rozmowy zakończyły się fiaskiem, jak słusznie zauważyła Justyna Głogowska, na całym wydarzeniu wyraźnie zyskała Turcja, która po raz kolejny dowiodła, że jest wiarygodnym partnerem zarówno dla Iranu, jak i całej społeczności międzynarodowej, ze szczególnym wyróżnieniem państw Zachodu ${ }^{44}$.

Turcja reprezentuje niezmienne stanowisko w sprawie irańskiego programu nuklearnego od początku rządów partii AKP. Mieści się ono w szerszym kontekście stosunków turecko-irańskich. Zdaniem Rahmana G. Bonaba można wyróżnić cztery przyczyny wyraźnej poprawy w ramach relacji Turcji z Iranem na początku XXI wieku. Pierwszą

40 Iran MPs Rally in Support of Egyptians, http://www.presstv.ir/detail/165000.html (13.02.2011).

41 K. Üstün, Turkey's Iran Policy: Between Diplomacy and Sanctions, „Insight Turkey” 2010, vol. 12 , no. 3 , s. 26 .

42 W skład grupy 5+1 wchodzą przedstawiciele pięciu państw posiadających status stałych członków Rady Bezpieczeństwa ONZ (Stany Zjednoczone, Federacja Rosyjska, Chińska Republika Ludowa, Francja, Zjednoczone Królestwo Wielkiej Brytanii i Irlandii Północnej) oraz Republiki Federalnej Niemiec.

43 Wspomniane rokowania miały miejsce w Stambule 21 stycznia 2011 roku. Więcej zob. F. Rahim, Iran, 5+1 talks to resume in Istanbul tomorrow, http://aknews.com/en/aknews/4/212135/ (21.01.2011). Ciekawy artykuł dotyczący dyplomacji energetycznej, ze szczególnym uwzględnieniem pozycji i potencjału Iranu zob. S. M. Hossein Adeli, The Contribution of Energy Diplomacy to International Security; with Special Emphasis on Iran, „Iranian Review of Foreign Affairs” 2010, vol. 1, no. 2 .

44 J. Głogowska, Turcja szuka przyjaźni z Iranem, http://www.stosunki.pl/?q=content/turcja-szuka-przyja\%C5\%BAni-z-iranem (13.02.2011). 
z nich jest zaufanie, jakim władze Iranu obdarzają turecki rząd zdominowany przez AKP. Odejście od niektórych zasad kemalizmu oraz podkreślenie roli islamu w życiu politycznym i społecznym Turcji doprowadziło do zbliżenia na linii Ankara-Teheran. Po drugie, Turcja wiele razy podkreślała znaczenie oraz pozytywną rolę Iranu w stabilizacji sytuacji w regionie Bliskiego Wschodu. Po trzecie, Iran postrzega Turcję jako bardziej niezależną aniżeli inne państwa w regionie. Dotyczy to także stosunków Turcji ze Stanami Zjednoczonymi za rządów AKP. Pierwszym przejawem jakościowej zmiany w stosunkach turecko-amerykańskich była odmowa Turcji w sprawie udostępnienia swego terytorium dla sił koalicji, przygotowujących się do ataku na Irak w 2003 roku $^{45}$. Czwarty argument dotyczy zmiany w ramach irańskiej polityki zagranicznej. Iran stopniowo zacieśnia kontakty z sąsiednimi państwami. W przypadku Turcji wykracza poza dotychczasową współpracę, która ograniczała się głównie do kwestii kurdyjskiej ${ }^{46}$. Na przykład, w 2004 roku premier Erdoğan odwiedził Iran. Podczas spotkania została podpisana umowa dotycząca wspólnych działań przeciwko partyzantom kurdyjskiej PKK, określonej w dokumencie mianem „grupy terrorystycznej”, ${ }^{, 7}$.

Zbliżeniu politycznemu pomiędzy Turcją a Iranem towarzyszy także zacieśnianie stosunków handlowych. Już w tej chwili Iran jest jednym z najważniejszych partnerów handlowych Turcji. Wartość wymiany handlowej wzrosła z 2,3 mld dolarów w 2004 roku do 10,2 mld dolarów w roku $2008^{48}$. Najważniejszym elementem współpracy gospodarczej pomiędzy Iranem a Turcją jest handel surowcami, a także kooperacja w obszarze rozbudowy infrastruktury przesyłowej ${ }^{49}$. Od wielu lat Turcja jest bardzo zainteresowana importem irańskiego gazu ziemnego, stanowiącego alternatywę dla dominujących obecnie dostaw tego surowca z Federacji Rosyjskiej oraz umożliwieniem jego dalszego przesyłu do Europy przez własne terytorium. Sytuację póki co komplikuje stanowcze stanowisko Stanów Zjednoczonych, które obawiają się zbliżenia pomiędzy Ankarą i Teheranem. Niemniej w ostatnich latach Turcja podjęła co najmniej kilka decyzji dotyczących zacieśnienia współpracy energetycznej z Iranem. W styczniu 2011 roku turecki minister do spraw energii i surowców naturalnych Taner Y1ldız potwierdził, że Iran jest i będzie drugim najważniejszym po Rosji dostawcą gazu ziemnego do Turcji. Jego irański odpowiednik Majid Namjou potwierdził przy okazji prowadzenie dwustronnych prac nad mapą drogową w obszarze współpracy energetycznej. W jednym z wywiadów udzielonych w styczniu 2011 r. stwierdził: „W obszarze współpracy energetycznej obie strony opracują całościowy plan, czyli mapę drogową. W przyszłości sektor energii będzie stanowił jeden z filarów współpracy turecko-irańskiej”, ${ }^{\circ 0}$.

Bez wątpienia współpraca w dziedzinie energetycznej leży u podstaw konsekwentnej polityki władz Turcji dotyczącej sprzeciwu wobec nakładania kolejnych sankcji na

45 Więcej na ten temat zob. W. Hale, Turkey, the US and Iraq, Saqi, London 2007.

46 R. G. Bonab, Turkey's Emerging Role as a Mediator on Iran's Nuclear Activities, „Insight Turkey" 2009, vol. 11, no. 3, s. 170-171.

47 T. Y. Ismael, J. S. Ismael, Government and Politics of the Contemporary Middle East: Continuity and Change, Routledge, Abingdon 2011, s. 110.

48 J. Głogowska, Turcja szuka przyjaźni z Iranem, op. cit.

49 B. Aras, Turkey and the Greater Middle East, Tasam Publications, Istanbul 2004, s. 78.

50 Turkey Eager to Boost Oil, Gas Cooperation with Iran, http://english.farsnews.com/newstext.php?nn=8911050426 (27.01.2011). 
Iran przez RB ONZ. Nałożenie na Iran jakichkolwiek dodatkowych ograniczeń w handlu gazem bez wątpienia uderzyłoby również w Turcję. Niemniej, należy zauważyć, że nawet pomijając negatywne konsekwencje sankcji, Iran nie jest dla Turcji stabilnym, w pełni przewidywalnym partnerem. Zimą często dochodzi do zmniejszenia ilości gazu eksportowanego do Turcji, co irańskie władze usprawiedliwiają rosnącym zapotrzebowaniem na rynku wewnętrznym. Co więcej, Iran ostrzega, że jeśli nie uda się wybudować wydajnych elektrowni atomowych, za kilkanaście lat będzie zmuszony zawiesić sprzedaż, a wręcz może stać się importerem gazu ${ }^{51}$.

$\mathrm{O}$ istotnej poprawie w stosunkach turecko-irańskich świadczą także wypowiedzi czołowych polityków. Murat Mercan, przewodniczący komisji spraw zagranicznych Wielkiego Zgromadzenia Narodowego Turcji, stwierdził na początku 2010 roku: „Turcję łączą z Iranem więzy historyczne, kulturowe i religijne. Inaczej mówiąc, Irańczycy są nie tylko naszymi sąsiadami, ale także przyjaciółmi i braćmi. Żaden turecki obywatel nie może zaakceptować faktu niesprawiedliwego traktowania irańskich sióstr i braci ze strony społeczności międzynarodowej. [...] Wierzę, że przyszłość Iranu powinna zależeć od Irańczyków. [...] Dlatego społeczność międzynarodowa powinna powstrzymać się od jakiejkolwiek próby ingerencji w sprawy Iranu, która źle wpłynęłaby na społeczną i polityczną sytuację w tym państwie",52. Warto podkreślić, że już w 2003 roku tureckie władze krytycznie oceniały zaliczenie Iranu do grupy państw osi zła przez administrację amerykańską ${ }^{53}$.

\section{STOSUNKI IRAŃSKO-TURECKIE: KATALOG ROZBIEŻNOŚCI}

Pomimo licznych zbieżnych interesów, zauważyć należy także rozbieżności w stosunkach irańsko-tureckich. Nur Bilge Criss i Serdar Güner podkreślili znaczenie podstawowych różnic w odniesieniu do geopolitycznego położenia Turcji i Iranu. Główna różnica dotyczy powiązań traktatowych, a zwłaszcza członkostwa Turcji w niechętnej Iranowi Organizacji Paktu Północnoatlantyckiego. Z kolei Iran pozostaje od lat w politycznej izolacji i nie zawiera sojuszy z innymi państwami ${ }^{54}$. O ile w ostatniej dekadzie można było zaobserwować wyraźne zbliżenie polityczne czy ekonomiczne pomiędzy Turcją i Iranem, tego samego nie można powiedzieć o współpracy wojskowej. Główną przeszkodą pozostają z pewnością stanowiska Stanów Zjednoczonych czy NATO, które Turcja musi uwzględniać. Ponadto, tureckie władze, zaniepokojone potencjalnym rozwojem irańskiego, wojskowego programu atomowego, nie są zainteresowane militarnym umacnianiem wschodniego sąsiada.

51 Turkey and Europe: the Way Ahead, International Crisis Group, Europe Report 17 August 2007, No. 184, s. 8.

${ }_{52}$ M. Mercan, Turkish Foreign Policy and Iran, „Turkish Policy Quarterly” 2010, vol. 8, nr 4, s. 19.

53 Nie tylko tureckie władze krytycznie wypowiadały się o polityce Stanów Zjednoczonych względem Iranu po zamachach z 11 września 2001 roku. Zob. G. A. M. Davies, Strategic Cooperation, the Invasion of Iraq and the Behaviour of 'the Axis of Evil', 1990-2004, „, Journal of Peace Research" 2008, vol. 45, no. 3 .

${ }^{54}$ N. B. Criss, S. Güner, Geopolitical Configurations: The Russia-Turkey-Iran Triangle, „Security Dialogue" 1999, vol. 30, no. 3, s. 366. 
Zdaniem Gregory L. Schulte'go, byłego przedstawiciela Stanów Zjednoczonych przy Międzynarodowej Agencji Energii Atomowej, Turcja nie powinna wstrzymywać się od głosu podczas głosowań w sprawie nakładania sankcji na Iran w Radzie Bezpieczeństwa ONZ. Jak twierdzi, „Turcja musi wypełnić przyjęte zobowiązania. Jeśli chce odnieść sukces dyplomatyczny, musi przyłączyć się do wspólnych działań, które mają postawić irańskich przywódców przed wyraźnym wyborem - albo poważne negocjacje, albo dotkliwe sankcje" ${ }^{95}$. Pytanie jednak czy w obecnej sytuacji leży to w interesie Turcji. Głosując za wprowadzeniem sankcji Turcja nie poprawiłaby znacznie swojej pozycji w stosunkach z Zachodem, natomiast taka decyzja z pewnością negatywnie wpłynęłaby na relacje z Iranem. Jak już wcześniej wspomniano, Turcja nie może sobie pozwolić na utratę dostaw irańskich surowców, zwłaszcza gazu ziemnego. Ewentualne napięcie polityczne na linii Ankara-Teheran mogłoby doprowadzić do częściowego lub nawet całkowitego zablokowania dostaw.

Pomimo wielu przykładów dwustronnej współpracy, Turcja i Iran nadal rywalizują ze sobą o wpływy na Bliskim Wschodzie. Ponadto, zarówno Turcja, jak i Iran, rywalizują o wpływy na Kaukazie oraz w Azji Środkowej. Jak słusznie zauważył Bülent Aras, po rozwiązaniu Związku Radzieckiego w Azji Środkowej powstała polityczna próżnia. Niemalże od razu wśród wielu analityków amerykańskich zaczęło dominować przekonanie, iż próżnia ta, w obliczu słabości Rosji, zostanie z czasem wypełniona albo przez Turcję, albo przez Iran. Oczywiście z zachodniej perspektywy było pożądane, by rywalizacja geopolityczna $\mathrm{w}$ tej części kontynentu azjatyckiego zakończyła się po myśli Turcji. W rezultacie pojawiły się liczne argumenty, które miały wspierać tureckie stanowisko, na przykład, podkreślając wspólnotę językową i kulturową pomiędzy Turkami a innymi tureckimi narodami w regionie Azji Środkowej czy uwypuklając zagrożenie ze strony fundamentalistów ${ }^{56}$.

Irańskie władze nieufnie podchodzą również do bliskich relacji Turcji z Izraelem. Bez wątpienia stosunki turecko-izraelskie były poprawne do maja 2010 roku, później uległy jednak wyraźnemu ochłodzeniu po ataku na statki płynące z pomocą humanitarną dla Palestyńczyków ze Strefy Gazy, podczas którego z rąk izraelskich komandosów śmierć poniosło dziewięciu Turków ${ }^{57}$. Nie zmienia to jednak faktu, że Turcja nadal blisko współpracuje z Izraelem, także, a może nawet przede wszystkim w dziedzinie wojskowości. I chociaż kooperacja odbywa się w dużej mierze pod kuratelą ze strony Stanów Zjednoczonych, oba państwa czerpią z niej wyraźne korzyści.

\section{IMPLIKACJE DLA REGIONU BLISKIEGO WSCHODU}

Wyraźna poprawa w ramach dwustronnych stosunków Iranu z Turcją przekłada się na wzrost poziomu bezpieczeństwa na Bliskim Wschodzie. Dzięki polityce eliminacji

55 G. L. Schulte, Why Turkey Cannot Abstain on Iran's Nuclear Violations, ,Turkish Policy Quarterly" 2010, vol. 8, no. 4, s. 26.

56 B. Aras, Turkey and the Greater Middle East, op. cit., s. 75.

57 T. Y. Ismael, J. S. Ismael, Government and Politics of the Contemporary Middle East: Continuity and Change, op. cit., s. 110-111. W literaturze anglojęzycznej używany jest termin „the May 2010 flotilla incident". 
problemów w stosunkach z państwami sąsiednimi, Turcji udało się doprowadzić do zbliżenia z Syrią. Z pewnością nie byłoby to możliwe bez akceptacji ze strony Iranu, który łączą z Syrią szczególne więzy polityczne ${ }^{58}$.

Turcja z pewnością nie jest i nie będzie zainteresowana jakąkolwiek destabilizacją w Libanie, co może mieć wpływ na wynik rywalizacji głównych sił politycznych w tym państwie. Powszechnie wiadomo, że libańska Partia Boga (Hezbollah), wspierana przez Iran, dąży do przejęcia władzy w Libanie i utworzenia republiki islamskiej na wzór Iranu, ale taki scenariusz nie jest z kolei korzystny dla Turcji, która preferuje pozostanie u władzy sił umiarkowanych. Zarówno Iran, jak i Turcja mogą się zatem wzajemnie blokować, zapewniając Libanowi względny spokój i stabilizację polityczną. Polityczne przesilenie w Libanie z lutego 2011 roku było z pewnością niekorzystne z punktu widzenia Turcji, niemniej trudno sobie wyobrazić, by Turcja przyzwoliła na utworzenie libańskiej republiki islamskiej. Irańskie władze z kolei nie zaryzykuja, przynajmniej w przewidywalnej perspektywie, dobrych stosunków z Turcją dla zwiększenia i tak już znacznych wpływów politycznych w Libanie ${ }^{59}$.

Turcja stopniowo odbudowuje swoją pozycję w państwach arabskich, zwłaszcza w regionie Zatoki Perskiej. Jej pośrednictwo w kontaktach tych państw z Iranem może okazać się bardzo korzystne, pomimo wyraźnej rywalizacji na tle różnic wyznaniowych czy politycznych.

Zbliżenie irańsko-tureckie z pewnością komplikuje i ogranicza możliwości działania Stanów Zjednoczonych na Bliskim Wschodzie. O ile od 1979 roku USA nie mogą liczyć na współpracę ze strony Iranu, do momentu dojścia do władzy AKP w 2002 roku zawsze mogły liczyć na Turcję. Obecnie sytuacja jest o wiele bardziej złożona, a administracja amerykańska często natrafia na sprzeciw, gdy tylko próbuje skrytykować stanowisko tureckich władz, na przykład, w kwestii nakładania kolejnych sankcji na Iran przez Radę Bezpieczeństwa ONZ, politycznego zbliżenia Turcji z Syrią czy dialogu z przedstawicielami Hamasu. Zdaniem Roberta Malleya i Petera Harlinga, nowy układ sił na Bliskim Wschodzie stanowi największe międzynarodowe wyzwanie dla administracji prezydenta Baracka Obamy. Odzyskanie wpływów utraconych w wyniku błędnych decyzji poprzedniej administracji George'a W. Busha może okazać się już niemożliwe. Co więcej, Stany Zjednoczone mogą nadal stopniowo tracić na znaczeniu w regionie ${ }^{60}$. Kluczowe dla Amerykanów jest zatem stanowisko Turcji, bez której USA nie mogłyby już teraz skutecznie zabezpieczać własnych interesów na Bliskim Wschodzie. Stany Zjednoczone potrzebują także tureckiego pośrednictwa w kontaktach z Iranem. Między innymi powyższymi względami należy tłumaczyć determinację i konsekwencję, z jaką amerykańska administracja zachęca Unię Europejską do przyjęcia Turcji. Turcja trwale związana ze strukturami europejskimi i euroatlantyckimi będzie gwaran-

58 O stosunkach Iranu z Syrią zob. J. M. Goodarzi, Syria and Iran: Diplomatic Alliance and Power Politics in the Middle East, Tauris, London 2006.

59 Więcej na temat sytuacji politycznej w Libanie zob. M. Deeb, Syria's Terrorist War on Lebanon and the Peace Process, Palgrave Macmillan, New York 2003; S. Mackey, Mirror of the Arab World: Lebanon in Conflict, W.W. Norton \& Company, New York 2008; D. Madeyska, Liban, Wydawnictwo Trio, Warszawa 2003.

${ }^{60}$ R. Malley, P. Harling, Beyond Moderates and Militants. How Obama Can Chart a New Course in the Middle East, „Foreign Affairs” 2010, vol. 89, no. 5, s. 29. 
tem wpływów Zachodu na Bliskim Wschodzie, także w Iranie. Pojawia się jedynie wątpliwość czy tureckie władze zawsze będą zainteresowane taką rolą.

Analizując implikacje zbliżenia turecko-izraelskiego dla Bliskiego Wschodu, nie sposób pominąć bieżącej polityki obu państw wobec Izraela. Do niedawna Turcja niemalże w każdej sytuacji wspierała lub w sposób milczący akceptowała politykę zagraniczną Izraela. Ofra Bengio określiła nawet bliską współpracę izraelsko-turecką mianem filaru polityki zagranicznej USA na Bliskim Wschodzie ${ }^{61}$. Stosunki dwustronne Izraela z Turcją uległy jednak znacznemu pogorszeniu po izraelskiej interwencji w Strefie Gazy w 2009 roku $^{62}$. Ponadto, zdecydowana polityka izraelskiego rządu Beniamina Netanjahu, zwłaszcza w kwestii blokady Strefy Gazy, służy zbliżeniu turecko-irańskiemu i pozbawia społeczność międzynarodową ważnego mediatora, jakim do tej pory bywała Turcja. W opinii Juan Cole, umacnia także władzę sił konserwatywnych w Iranie ${ }^{63}$. Po incydencie z maja 2010 roku izraelskie władze nie postrzegają już Turcji jako pośrednika, lecz raczej jako rywala oraz stronniczkę Palestyńczyków i wrogo nastawionych do Izraela państw arabskich czy Iranu. To cena, którą płaci Turcja za wolę politycznego przywództwa wśród państw muzułmańskich Bliskiego Wschodu. Tym samym trudno zakładać możliwy udział Turcji w ewentualnych negocjacjach Syrii z Izraelem czy Egiptu z Izraelem, jeśli egipskie wybory jesienią 2011 roku zakończyłyby się zwycięstwem sił o orientacji antyizraelskiej.

Podczas minionej dekady stosunki turecko-irańskie uległy istotnej poprawie. Dotychczasowa rywalizacja w obszarach wyznaniowym, politycznym czy gospodarczym stopniowo ustępuje miejsca współpracy. Władze obu państw mają świadomość, iż długofalowa współpraca jest dla nich korzystniejsza aniżeli rywalizacja w doraźnych sytuacjach. Jak słusznie zauważa Graham E. Fuller, według wszystkich przewidywalnych scenariuszy Iran będzie ,przewrażliwionym, ale stałym partnerem Turcji”64 .

Pomimo wielu różnic, władze Iranu i Turcji zdają sobie sprawę z korzystnego wpływu swojej współpracy na polityczną sytuację na Bliskim Wschodzie. Polityka Turcji względem zarówno Iranu, jak i państw arabskich przyczynia się do stabilizacji i zagwarantowania bezpieczeństwa w regionie.

Należy bardzo pozytywnie ocenić zaangażowanie oraz działania podejmowane przez władze Turcji celem dyplomatycznego rozwiązania problemu irańskiego programu atomowego. Stanowisko Turcji może nie tylko przyczynić się do zmniejszenia ryzyka wystapienia kryzysu, ale wręcz stanowić gwarancję bezpieczeństwa i pokoju w regionie.

61 O. Bengio, The Turkish-Israeli Relationship: Changing Ties of Middle Eastern Outsiders, Palgrave Macmillan, New York 2010, s. 168.

62 Więcej o sytuacji w Strefie Gazy zob. E. Jasiewicz, Podpalić Gazę, Wydawnictwo W.A.B., Warszawa 2011.

63 J. Cole, How Israel's Gaza Blockade and Washington's Sanctions Policy Hurt the Green Movement and Helped Keep Iran's Hardliners in Powers, w: The People Reloaded: The Green Movement and the Struggle for Iran's Future, eds. N. Hashemi, D. Postel, Melville House, New York 2010, s. 321-322.

${ }^{64}$ G. E. Fuller, The New Turkish Republic. Turkey As a Pivotal State in the Muslim World, op. cit., s. 114. 
Na szczególną uwagę zasługuje irańsko-turecka współpraca w dziedzinie bezpieczeństwa energetycznego, zwłaszcza w kontekście wydobycia i przesyłu surowców. Priorytet stanowią wspólne projekty dotyczące rynku gazu ziemnego. Mogą na niej skorzystać także pozostałe państwa regionu.

Pomimo przytoczonych powyżej argumentów, nie można zapominać o rozbieżnościach i sprzecznych interesach między Turcją a Iranem. Z pewnością najważniejsza różnica dotyczy kwestii ustrojowych, ideologicznych, które determinują cele oraz sposób realizacji polityki zagranicznej w obu państwach. Nakładają się na to różnice wyznaniowe. Pomimo upływu setek lat konflikt pomiędzy sunnitami a szyitami nie traci ani na sile, ani na znaczeniu. Nie bez znaczenia pozostaje także kwestia rywalizacji geopolitycznej na Kaukazie, w rejonie Zatoki Perskiej czy w Azji Środkowej. W przypadku Azji Środkowej istnieje jednak szansa na współpracę irańsko-turecką w odpowiedzi na coraz silniejszą pozycję Chińskiej Republiki Ludowej w tej części świata. Podobną sytuację można zaobserwować na Kaukazie, ponieważ oba państwa obawiają się ewentualnej, politycznej ekspansji Federacji Rosyjskiej.

Nie ulega wątpliwości, że coraz lepsze stosunki irańsko-tureckie będą miały pozytywny wpływ na układ sił oraz poziom bezpieczeństwa na Bliskim Wschodzie. W obliczu napięć pomiędzy Iranem a Stanami Zjednoczonymi czy Izraelem, Turcja, pomimo głębokich przemian w ramach polityki wewnętrznej, nadal będzie odgrywała istotna, łagodząca rolę, pozwalającą zabezpieczyć pokój w regionie. Obecne zbliżenie Iranu i Turcji nie powinno zatem wywoływać zaniepokojenia w Unii Europejskiej czy Stanach Zjednoczonych, gdyż nie ma antyzachodniego wymiaru. Wręcz przeciwnie, współpraca na linii Ankara-Teheran winna być postrzegana jako pierwszy, ważny krok w kierunku ostatecznego rozwiązania sporów i konfliktów oraz stabilizacji politycznej na Bliskim Wschodzie.

\title{
STRESZCZENIE
}

Turcja i Iran należą bez wątpienia do grupy regionalnych mocarstw na Bliskim Wschodzie. Porównywalnym potencjałem dysponują jeszcze tylko dwa państwa - Arabia Saudyjska oraz Egipt. Jednak to właśnie Turcja i Iran, zwłaszcza w porównaniu z innymi państwami w regionie, dysponują największym potencjałem demograficznym, politycznym, gospodarczym oraz militarnym. Niniejszy artykuł poświęcony jest analizie stosunków irańsko-tureckich w pierwszej dekadzie XXI wieku, gdy zauważalne stało się polityczne i ekonomiczne zbliżenie pomiędzy Turcją $\mathrm{i}$ Iranem. Tym samym najważniejsze pytanie dotyczy przyczyn takiego stanu rzeczy oraz możliwych implikacji dla całego regionu Bliskiego Wschodu.

\section{TURKISH-IRANIAN RELATIONS AT THE TURN OF THE CENTURY: IMPLICATIONS FOR THE MIDDLE EAST}

\author{
ABSTRACT \\ Both Turkey and Iran are perceived as regional powers of the Middle East. Although Saudi \\ Arabia and Egypt are also key players in the region, Iran and Turkey have tremendous potential
}


in terms of politics, economy, demography as well as military power. This article is dedicated to the analysis of Turkish-Iranian relations at the beginning of the $21^{\text {st }}$ Century. Undoubtedly, current political and economic rapprochement between these two states is noticeable. Yet the most important questions concern the reasons for it as well as possible implications for the Middle East. 